\title{
Erratum to: A case of B-cell acute lymphoblastic leukemia in a child with Down syndrome bearing a t(2;12)(p12;p13) involving ETV6 and biallelic IGH@ rearrangements
}

\author{
Carlos A. Tirado ${ }^{*}$, David Shabsovich ${ }^{\dagger}$, Yeun Kim, Peter Traum, Sheeja Pullarkat, Michael Kallen and Nagesh Rao
}

The original version of this article [1] unfortunately contained mistakes.

The metaphase FISH studies using the Vysis IGH Dual Color, Break Apart Rearrangement Probe revealed 1 fusion signal on the normal chromosome 14 corresponding to an intact IGH@ locus, a red signal corresponding to the 3' region of the IGH@ locus on the derivative chromosome 14, and a green signal corresponding to the 5' region of the IGH@ locus on the derivative chromosome 8 . This was not described correctly in the results section of the original manuscript.

Additionally, in the discussion, the reference for the case bearing the concomitant $\mathrm{t}(8 ; 14)(\mathrm{q} 11.2 ; \mathrm{q} 32)$ and del(12)(p12p13) should be Byatt et al., not Harrison et al.

Finally, the email of the corresponding author (Carlos Tirado) should be ctirado@mednet.ucla.edu.

Received: 26 October 2015 Accepted: 27 October 2015

Published online: 02 November 2015

\section{Reference}

1. Tirado CA, Shabsovich D, Kim Y, Traum P, Pullarkat S, Kallen M, et al. A case of B-cell acute lymphoblastic leukemia in a child with Down syndrome bearing a t(2;12)(p12;p13) involving ETV6 and biallelic IGH@ rearrangements. Biomark Res. 2015;3:11.

\footnotetext{
* Correspondence: ctirado@mednet.ucla.edu

'Equal contributors

Department of Pathology and Laboratory Medicine, David Geffen School of Medicine at UCLA, Los Angeles, CA, USA
}

\section{Submit your next manuscript to BioMed Centra and take full advantage of: \\ - Convenient online submission \\ - Thorough peer review \\ - No space constraints or color figure charges \\ - Immediate publication on acceptance \\ - Inclusion in PubMed, CAS, Scopus and Google Scholar \\ - Research which is freely available for redistribution}

Submit your manuscript at

www.biomedcentral.com/submit

C) Biomed Central 